\title{
Epidemiology of malaria in the Taabo health and demographic surveillance system, south-central Côte d'Ivoire
}

\author{
Fidèle K. Bassa 1,2*, Mamadou Ouattara' ${ }^{1}$, Kigbafori D. Silué ${ }^{1,2}$, Lukas G. Adiossan³, Nahoua Baikoro², Siaka Koné2,
} Moussan N'Cho ${ }^{4}$, Mahamadou Traoré2, Bassirou Bonfoh², Jürg Utzinger ${ }^{5,6}$ and Eliézer K. N'Goran ${ }^{1,2}$

\begin{abstract}
Background: A deep understanding of the local epidemiology of malaria is essential for the design and implementation of setting-specific control and elimination efforts. In Côte d'Ivoire, new initiatives are underway to reduce the burden of malaria, which requires high-quality longitudinal data. The epidemiology of malaria was studied in the Taabo health and demographic surveillance system (HDSS) in south-central Côte d'Ivoire and implications for control are discussed.

Methods: Two cross-sectional surveys were carried out in the rainy season of June/July in 2010 and 2011. Inhabitants of approximately $7 \%$ of randomly selected households in the Taabo HDSS were invited to participate. People were clinically examined, ear temperature was measured and spleen size determined. Finger-prick blood samples were collected and subjected to a rapid diagnostic test (RDT). Additionally, thick and thin blood films were prepared on microscope slides and diagnosed under a microscope for Plasmodium infection and parasitaemia. Haemoglobin (Hb) level was determined using a HemoCue device.

Results: A total of 1187 and 1264 people in 2010 and 2011, respectively, had complete data records. The prevalence of Plasmodium infection was $46.0 \%$ in 2010 and $56.6 \%$ in 2011, owing to a statistically significant difference $(p<0.05)$. Males showed a higher Plasmodium infection prevalence than females ( 49.6 and $62.8 \%$ versus 42.6 and $51.2 \%$; respectively, in 2010 and 2011; both $p<0.05$ ). The highest malaria prevalence was observed among infants and young children (aged $\leq 9$ years). The risk of Plasmodium infection was significantly higher in villages compared to small hamlets and urban settings $(p<0.05)$. Fever, $\mathrm{Hb}$ level and splenomegaly were associated with parasitaemia.
\end{abstract}

Conclusion: Malaria is highly endemic in the Taabo HDSS in south-central Côte d'Ivoire with considerable spatial heterogeneity of Plasmodium infection. There is a pressing need to scale-up control interventions against malaria.

Keywords: Malaria, Plasmodium, Health and demographic surveillance system, Cross-sectional survey, Côte d'Ivoire

\section{Background}

Substantial progress has been made in the understanding of the epidemiology of malaria and ways to control or eliminate the disease. In particular, integrated approaches using vector control measures, e.g. long-lasting insecticidal nets (LLINs) and artemisinin-based combination

\footnotetext{
*Correspondence: fidelebassa@ymail.com

${ }^{1}$ Unité de Formation et de Recherche Biosciences, Université Félix

Houphouët-Boigny, Abidjan, Côte d'Ivoire

Full list of author information is available at the end of the article
}

therapy (ACT) considerably reduced the burden of malaria over the last decade $[1,2]$.

In Côte d'Ivoire, an over 10-year long sociopolitical crisis jeopardized malaria control. Nevertheless, different initiatives have been implemented by the national malaria control programme with financial support from the Global Fund to Fight AIDS, Tuberculosis and Malaria. However, a clear downward trend in the number of malaria cases has yet to be registered [3]. It must be noted that there is a paucity of accurate and coherent information about the local epidemiology of malaria. 
Most of the recent data stem from Abidjan, the economic capital of Côte d'Ivoire, usually obtained from health facilities [4-6]. Although health facility-based data can be helpful for assessing the malaria burden, the data must be used with full recognition of their limitations, since many people may not seek treatment in a health facility [7] and diagnostic-treatment algorithms are often empirical [8]. It follows that population-based data using accurate diagnostic methods are needed to provide precise estimates of the disease burden in different regions and contexts, as malaria control efforts are being intensified.

The aim of the present study was to assess the local epidemiology of malaria in the Taabo health and demographic surveillance system (HDSS) of south-central Côte d'Ivoire [9]. An in-depth analysis of 712 deaths recorded in the Taabo HDSS between 2009 and 2011 revealed that malaria was the most important cause of death $(n=129$, $18.0 \%$ [10]. Here, results from two cross-sectional surveys conducted in the rainy season of 2010 and 2011 are reported.

\section{Methods \\ Ethical considerations}

The study protocol was approved by the institutional research commission of the Centre Suisse de Recherches Scientifiques en Côte d'Ivoire (CSRS; Abidjan, Côte d'Ivoire). Ethical approval was granted by the Comité National d'Ethique et de la Recherche (CNER) of Côte d'Ivoire (reference no. 1086 MSHP/CNER). Participation was voluntary and all study subjects provided written informed consent, with parents/legal guardians signing on behalf of children/adolescent below the age of 18 years.

\section{Study area}

The study was conducted in the Taabo HDSS, located in the Taabo district, some $150 \mathrm{~km}$ north-west of Abidjan. The Taabo HDSS is situated in a forest-savannah transitional zone and has a surface of approximately $1000 \mathrm{~km}^{2}$. At the onset of operation in late 2008/early 2009, the population in the Taabo HDSS was 37,792 inhabitants. There is a small town (Taabo-Cité), 13 main villages and over 100 small hamlets. The climate is tropical, with two rainy seasons (March to July and October/November) and two dry seasons (December to February and August/ September). Due to recent climate change, no clear seasonal delimitation is observed any longer and there is a tendency of just two seasons [11]. The average annual precipitation in the years $2010-2011$ was $1284 \mathrm{~mm}$, the mean annual temperature varied from 27.6 to $28.3{ }^{\circ} \mathrm{C}$ and the average relative humidity ranged between 76.6 and $79.6 \%$ (data obtained from the nearby Lamto Station for Research in Geophysics and Ecology). People in the
Taabo HDSS are mainly engaged in subsistence farming (yams, banana, maize and cassava). Cocoa and coffee are used as cash crops. There is also some livestock production (cattle, small ruminants, pigs and poultry) and fishery. A key environmental feature of the Taabo HDSS is the man-made Lake Taabo, impounded in the late 1970s after the construction of a large dam across the Bandama River, used for hydroelectric power production [12].

The Taabo HDSS has been launched in mid-2008 and serves as a platform for high-quality longitudinal data on all the residents, with particular emphasis on demography (pregnancy, birth, migration and death), health and socioeconomic status. Data are collected prospectively, usually pursuing three rounds per year to obtain key demographic data. Additionally, once every 2nd year, socioeconomic data are collected. The activities of the Taabo HDSS began by a baseline census in late 2008/ early 2009, during which all the households of the district of Taabo were visited and georeferenced. Data were collected on household composition, house characteristics, household asset ownership, people's ethnicity, nationality, religion, age, sex, education and employment.

From 2009 to 2011, community-based deworming against soil-transmitted helminthiasis (using albendazole or mebendazole) and schistosomiasis (using praziquantel) was undertaken in the whole area under surveillance under the leadership of district health personnel with support of Taabo HDSS staff. A series of specific research projects provided additional treatment to study participants found positive for specific parasitic infections $[9,13-15]$.

\section{Cross-sectional surveys}

Two cross-sectional surveys were conducted; in 2010 and 2011, during the main rainy season at the end of June/early July. Study participants were invited for a finger-prick blood sample that was utilized for measuring haemoglobin $(\mathrm{Hb})$ level, employing a HemoCue device (HemoCueB-Hemoglobin; Angholm, Sweden). Additionally, a rapid diagnostic test (RDT) was performed and thick and thin blood films were prepared on microscope slides for Plasmodium diagnosis. The RDT (ICT Diagnostics; Cape Town, South Africa) was used to detect Plasmodium falciparum histidine rich protein 2 (HRP 2). This RDT was shown to detect $86.9 \%$ of test samples with wild-type $P$. falciparum at a concentration of 200 parasites/ $\mu \mathrm{l}$ of blood and $98 \%$ of test samples with a concentration of 2000 parasites/ $\mu$ l of blood, with $0 \%$ of false positives in negative samples [16]. The results from the RDTs were used to guide treatment. Participants were also subjected to a clinical examination. Temperature was measured using a digital ear thermometer (Omron Gentle Temp 510; Kyoto, Japan). Spleen size was determined by a physician according to Hackett's grading [17]. 


\section{Sampling technique}

Study participants were selected from the readily available Taabo HDSS database. All members of approximately $7 \%$ of the households were selected in each of the two cross-sectional surveys. The sampling design was based on clusters stratified according to residency (i.e. hamlet, village and Taabo-Cité) and the geographical location of residency relative to the Bandama River and Lake Taabo. Four strata were distinguished: (1) households situated in hamlets that were at least $5 \mathrm{~km}$ away from the river or lake; (2) households located in hamlets in close proximity to the river or lake $(<5 \mathrm{~km})$; (3) households in the main villages far from the river or lake; and (4) households in the main villages in close proximity to the river or lake and households from urban Taabo-Cité. The total number of individuals invited to participate in the years 2010 and 2011 was 2530 and 2621, respectively. Households were randomly selected in each stratum with a probability proportional to their population size.

\section{Laboratory procedures}

Thick and thin blood films were transferred to the laboratory of the district hospital in Taabo-Cite and stained with $3 \%$ Giemsa for $45 \mathrm{~min}$. Parasitaemia was determined from thick blood films by counting the number of parasites per 200 white blood cells (WBC) or 500 WBC if less than 10 parasites had been detected, assuming a mean WBC count of $8000 / \mu \mathrm{l}$ of blood. A slide was classified as negative if no Plasmodium asexual form or gametocyte was found after counting 500 WBC. Thin blood films were examined for Plasmodium species identification, examining 100 microscopic fields. Quality control was performed by a senior technician, who was blinded to the results obtained from the first reader. Slides with conflicting results were re-read by a third microscopist and the results discussed among the technicians until consensus was reached.

\section{Statistical analysis}

Demographic, clinical and laboratory data were double entered and validated in an Access 2007 database (Microsoft Corp., Redmond, USA). Fever was defined as an ear temperature $\geq 37.5^{\circ} \mathrm{C}$. Anaemia was defined according to guidelines put forth by the World Health Organization (WHO) [18]. In brief, children below the age of four years were considered anaemic if they had an $\mathrm{Hb}$ level $<11.0 \mathrm{~g} /$ $\mathrm{dl}$; children aged 5-11 years if they had an $\mathrm{Hb}$ level $<11.5 \mathrm{~g} / \mathrm{dl}$; females aged 12-14 years who had an $\mathrm{Hb}$ level $<12.0 \mathrm{~g} / \mathrm{dl}$; females aged $\geq 15$ years with an $\mathrm{Hb}<12.0 \mathrm{~g} / \mathrm{dl}$; and males aged $\geq 13$ years who had an $\mathrm{Hb}<13.0 \mathrm{~g} / \mathrm{dl}$. To examine the effects of age on parasitaemia, age was stratified into six groups according to WHO guidelines [19]: $<1,1-4,5-9,10-14,15-19$ and $\geq 20$ years. The same stratification was used for fever and spleen size. Individuals with missing or incomplete data were excluded from specific analysis that requested a given parameter under consideration.

Descriptive statistics were used to summarize demographic characteristics of the study sample. Comparisons between groups for categorical parameters were carried out by the Pearson's $X^{2}$ test. Differences in geometric mean of parasitaemia, mean age and mean spleen size between groups were analysed by Wilcoxon test (two groups) or Kruskal-Wallis test (more than two groups) in case the Shapiro normality test was significant. Odds ratios (ORs) were estimated using logistic regression to compare the risk of Plasmodium infection between groups. For all analyses, difference was regarded as significant if the $p$ value of the test statistic was $<0.05$. Data analyses were performed using R statistics (R Core Team, 2013).

\section{Results}

\section{Demographic characteristics}

A total of 1187 and 1264 individuals participated in the cross-sectional surveys conducted in 2010 and 2011, respectively. The number of people sampled, stratified by age group, sex and residency, is summarized in Table 1. In both cross-sectional surveys, most of the participants were young children and adolescents (58.7-58.9\%). The average age was 20.8 years (range 1 month-87 years, standard deviation $(\mathrm{SD})=18.8$ years) in 2010 and 20.9 years (range 1 month-82 years, $\mathrm{SD}=19.1$ years) in 2011. There was no significant difference in the average age of participants in the two surveys.

\section{Plasmodium infection}

Table 2 summarizes the prevalence of Plasmodium infection, stratified by year of survey, participants' residency and sex. The overall prevalence of Plasmodium infection in 2011 was significantly higher than in 2010 (46.0 versus $56.6 \%$; $p<0.01$ ). Males showed a significantly higher prevalence of Plasmodium infection than females (49.6 and 62.8 versus 42.6 and $51.2 \%$; respectively, in 2010 and 2011; both $p<0.05$ ). The prevalence of Plasmodium infection was significantly higher among individuals living in villages compared to residents from small hamlets or urban settings $(p<0.001)$. Plasmodium infection occurred in all age groups. The highest prevalence of infection was observed in infants and young children (age $\leq 9$ years). Prevalence decreased with age (Fig. 1).

\section{Plasmodium species-specific prevalence rates}

Three human malaria species were detected in the study area: P. falciparum, Plasmodium malariae and Plasmodium ovale, with the former representing the predominant 
Table 1 Demographic characteristics of the sample populations in the Taabo HDSS, stratified by year of survey

\begin{tabular}{|c|c|c|c|c|}
\hline & \multicolumn{2}{|l|}{2010} & \multicolumn{2}{|l|}{2011} \\
\hline & $\mathbf{N}$ & $\%$ & $\mathbf{N}$ & $\%$ \\
\hline All participants & 1187 & 100 & 1264 & 100 \\
\hline \multicolumn{5}{|l|}{ Gender } \\
\hline Male & 575 & 48.4 & 588 & 46.5 \\
\hline Female & 612 & 51.6 & 676 & 53.5 \\
\hline \multicolumn{5}{|c|}{ Age group (years) } \\
\hline$<1$ & 46 & 3.9 & 49 & 3.9 \\
\hline $1-4$ & 179 & 15.1 & 189 & 14.9 \\
\hline $5-9$ & 245 & 20.6 & 273 & 21.6 \\
\hline $10-14$ & 165 & 13.9 & 181 & 14.3 \\
\hline $15-19$ & 62 & 5.2 & 52 & 4.1 \\
\hline$\geq 20$ & 490 & 41.3 & 520 & 41.2 \\
\hline \multicolumn{5}{|l|}{ Residency } \\
\hline Hamlets & 200 & 16.8 & 230 & 18.2 \\
\hline Villages & 782 & 65.9 & 871 & 68.9 \\
\hline Urban & 205 & 17.3 & 163 & 12.9 \\
\hline
\end{tabular}

$N$ Number of individuals

species (98.9 and $99.7 \%$ of all positive thick and thin blood films examined in 2010 and 2011, respectively). Plasmodium malariae accounted for 1.1 and $0.2 \%$ of the infections, respectively, while $P$. ovale was rarely observed (one mixed infection with P. falciparum in 2011).

\section{Plasmodium parasitaemia}

Most infections were of low to moderate parasitaemia (16-9999 parasites/ $\mu$ l of blood). The proportion of infections with high parasitaemia $(\geq 10,000$ parasites $/ \mu$ l of blood) was $8.6 \%$ in 2010 and $5.2 \%$ in 2011. The geometric mean parasitaemia of positive samples was similar in both years (Table 2). The geometric mean parasitaemia was higher in the youngest age groups, compared to older counterparts (Fig. 1). With regard to sex, the difference in the geometric mean parasitaemia showed no consistent difference. With regard to parasitaemia and participants' residency, there was no statistically significant difference in 2010. However, in 2011, parasitaemia was significantly higher in village residents compared to people living in small hamlets or the urban setting (Table 2).

\section{Fever prevalence and relation to Plasmodium infection}

Ear temperature measurements were available for 1095 and 1187 of the surveyed individuals in 2010 and 2011, respectively. Fever, as defined by an ear temperature $\geq 37.5{ }^{\circ} \mathrm{C}$, was found in $13.0 \%$ of the individuals tested with no difference between the two surveys. The occurrence of fever showed an association with area of residency; in 2010, a statistically significantly higher prevalence was found in rural compared to the urban area $(p<0.001)$. With regard to sex, no difference was found in the prevalence of fever (Table 3). Age was associated with fever; children were found with higher prevalence of fever than adults aged 20 years and above (Fig. 2a). Among the febrile individuals, $55.1 \%$ were Plasmodium-positive in 2010 and $67.1 \%$ in 2011, whereas among non-febrile individuals, the respective prevalences were 45.0 and $56.8 \%$. There was a significant association between Plasmodium infection and fever (Table 4).

Table 2 Prevalence of Plasmodium infection and geometric mean parasitaemia of the sample population in the Taabo HDSS

\begin{tabular}{|c|c|c|c|c|c|c|}
\hline & \multicolumn{4}{|c|}{ Prevalence of Plasmodium infection } & \multicolumn{2}{|c|}{$\begin{array}{l}\text { GMP (parasites/ } \mu \mathrm{l} \\
\text { of blood) }\end{array}$} \\
\hline & $2010(\%)$ & OR $(95 \% \mathrm{Cl})$ & $2011(\%)$ & OR (95 \% Cl) & 2010 & 2011 \\
\hline Overall & $46.0^{\mathrm{a}}$ & & $56.6^{\mathrm{b}}$ & & 632.5 & 520.6 \\
\hline \multicolumn{7}{|l|}{ Gender } \\
\hline Male & $49.6(285 / 575)$ & 1.00 & $62.8(369 / 588)$ & 1.00 & 617.9 & 479.1 \\
\hline Female & $42.6(261 / 612)$ & $0.8(0.60-0.95)^{\dagger}$ & $51.2(346 / 676)$ & $0.6(0.49-0.77)^{\dagger}$ & 648.8 & 568.7 \\
\hline$p$-value & $<0.05$ & & $<0.001$ & & 0.822 & 0.177 \\
\hline \multicolumn{7}{|l|}{ Residency } \\
\hline Hamlets & $40.0(80 / 200)$ & 1.00 & $49.1(113 / 230)$ & 1.00 & 678 & 401.7 \\
\hline Villages & $50.9(398 / 782)$ & $1.6(1.13-2.13)^{\dagger}$ & $60.5(527 / 871)$ & $1.6(1.18-2.12)^{\dagger}$ & 611.7 & $586.5^{\mathrm{a}}$ \\
\hline Urban & $33.2(68 / 205)$ & $0.7(0.49-1.11)$ & $46.0(75 / 163)$ & $0.9(0.59-1.31)$ & 708.8 & $332.8^{\mathrm{b}}$ \\
\hline$p$-value & $<0.001$ & & $<0.001$ & & 0.856 & 0.006 \\
\hline
\end{tabular}

For each parameter, different letters in the same row or column indicate that their difference is significant $(p<0.05)$

$\mathrm{Cl}$ confidence interval, GMP geometric mean parasitaemia, $O R$ odds ratio

+ Notes that $p$-value $<0.05$ 


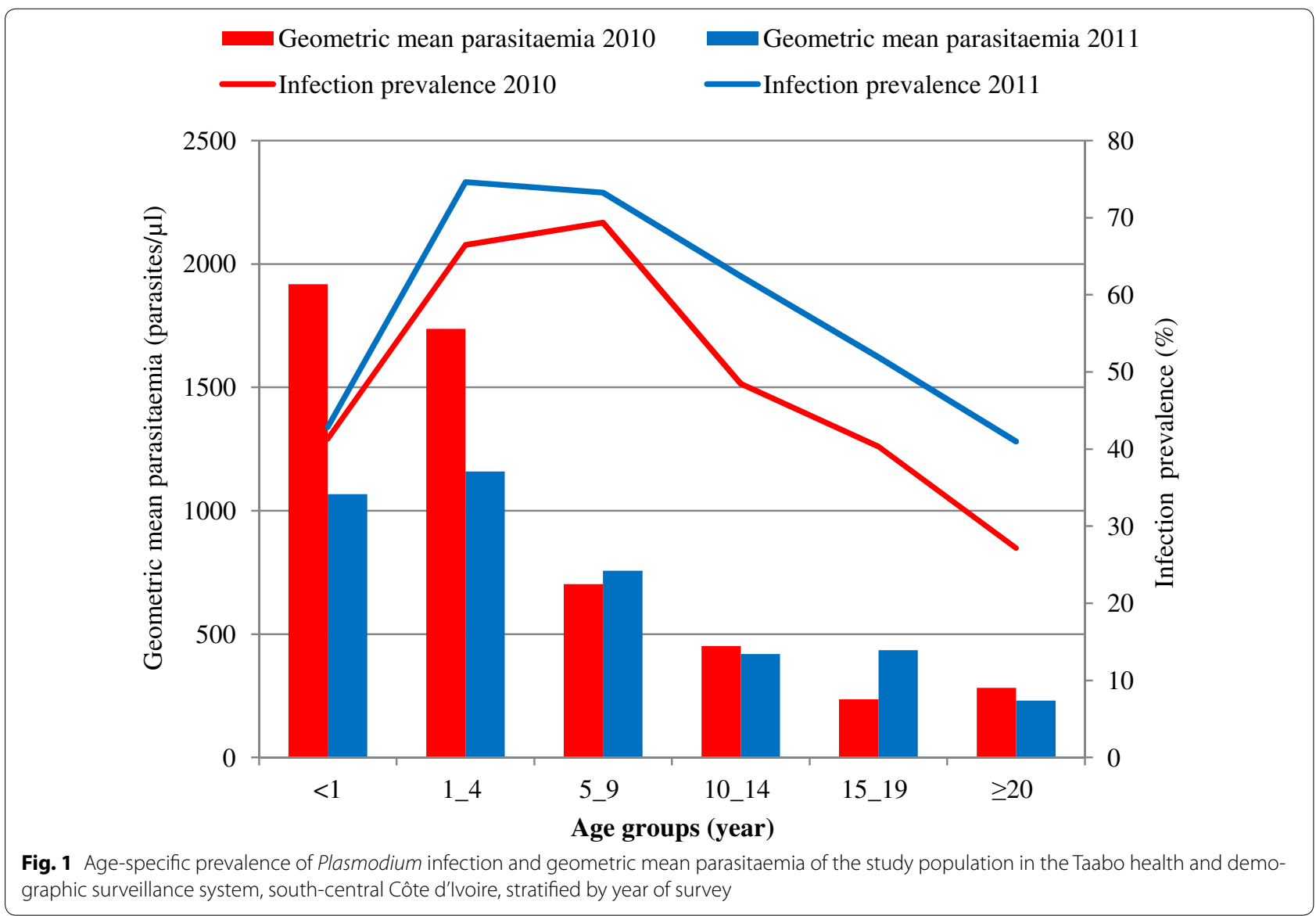

Table 3 Prevalence of fever and anaemia among the sample population in the Taabo HDSS, stratified by year of survey

\begin{tabular}{|c|c|c|c|c|}
\hline & \multicolumn{2}{|l|}{ Fever (\%) } & \multicolumn{2}{|l|}{ Anaemia (\%) } \\
\hline & $\begin{array}{l}2010 \\
(\mathrm{~N}=1095)\end{array}$ & $\begin{array}{l}2011 \\
(N=1187)\end{array}$ & $\begin{array}{l}2010 \\
(N=1087)\end{array}$ & $\begin{array}{l}2011 \\
(N=1196)\end{array}$ \\
\hline Overall & 13.4 & 13.3 & $47.6^{\mathrm{a}}$ & $37.3^{b}$ \\
\hline \multicolumn{5}{|l|}{ Gender } \\
\hline Male & $13.8(74 / 538)$ & $13.0(71 / 548)$ & $45.0(241 / 536)$ & $34.3(190 / 554)$ \\
\hline Female & $13.1(73 / 557)$ & $13.6(87 / 639)$ & $50.1(276 / 551)$ & $39.9(256 / 642)$ \\
\hline$p$-value & 0.821 & 0.804 & 0.102 & 0.053 \\
\hline \multicolumn{5}{|l|}{ Residence } \\
\hline Hamlets & $15.4^{\mathrm{a}}(29 / 188)$ & $17.9(34 / 190)$ & $45.7(84 / 184)$ & $38.2(73 / 191)$ \\
\hline Villages & $15.2^{\mathrm{a}}(109 / 718)$ & $12.9(110 / 851)$ & $49.0(350 / 714)$ & $37.7(323 / 856)$ \\
\hline Urban & $4.8^{\mathrm{b}}(9 / 189)$ & $9.6(14 / 146)$ & $43.9(83 / 189)$ & $33.6(50 / 149)$ \\
\hline$p$-value & $<0.001$ & 0.069 & 0.380 & 0.600 \\
\hline
\end{tabular}

For each variable, different letters in the same row or column indicate that their difference is significant at level of 0.05

$N$ total number of individuals examined
Of the Plasmodium-positive individuals, depending on the year of survey, the proportion of fever cases ranged between 15.4 and $15.9 \%$. Significantly more fever cases were found among heavily infected individuals (parasitaemia $\geq 10,000$ parasites/ $\mu$ l of blood) compared to those with only light or moderate infection (28.9-45.9 versus $13.6-14.7 \% ; p<0.05)$.

\section{Anaemia and relationship with Plasmodium infection}

$\mathrm{Hb}$ measurements were available for 1087 and 1196 individuals in 2010 and 2011, respectively, which allowed estimating the prevalence of age- and sex-specific anaemia. In the 2010 cross-sectional survey, anaemia was determined in $47.6 \%$ of the individuals. One year later, the proportion of anaemic individuals was considerably lower; $37.3 \%(p<0.01)$ (Table 3$)$. In both surveys, rates of anaemia were similar between males and females and place of residency (Table 3). There was a tendency for the proportion of anaemic individuals to decrease with 


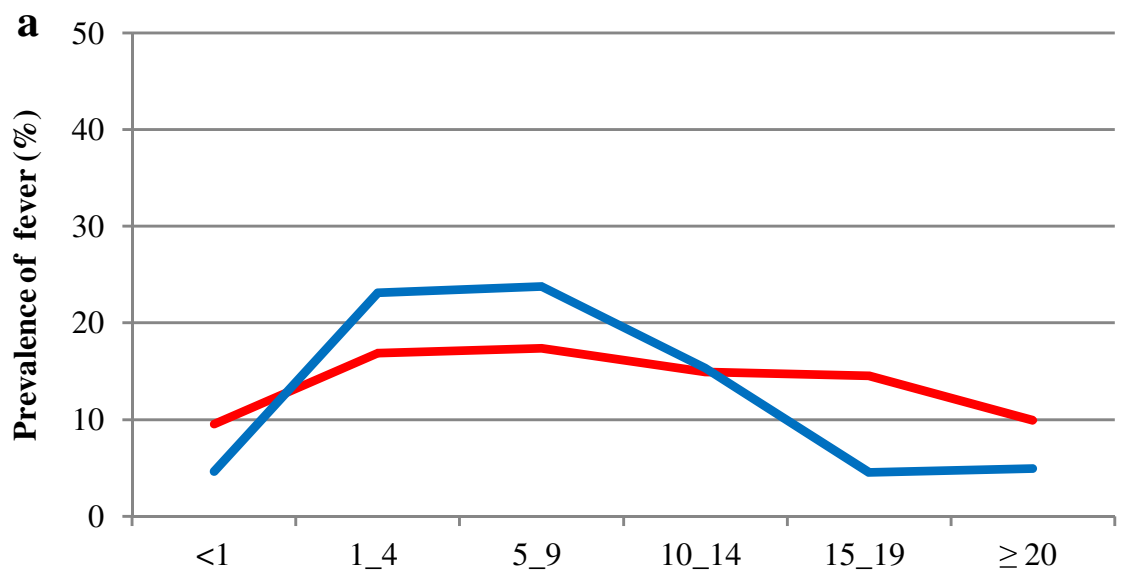

Age groups (year)
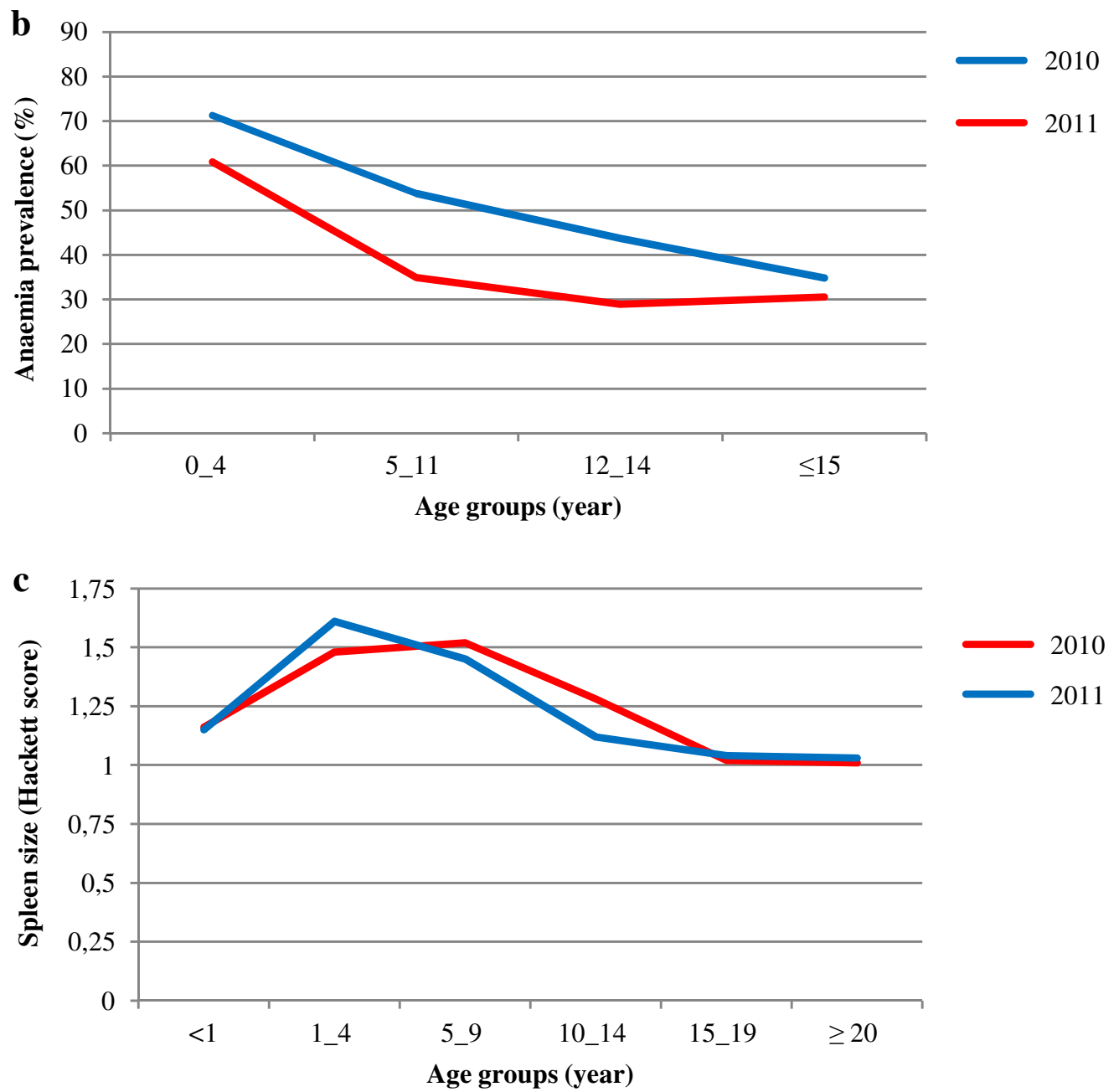

Fig. 2 Age-specific prevalence of fever (a), anaemia (b) and mean spleen size (c) of the study population in the Taabo HDSS 
Table 4 Relations between Plasmodium infection and fever, anaemia and splenomegaly in the Taabo HDSS, stratified by year of survey

\begin{tabular}{|c|c|c|c|c|}
\hline \multirow[t]{2}{*}{ Thick film } & \multicolumn{2}{|l|}{2010} & \multicolumn{2}{|l|}{2011} \\
\hline & Fever - & Fever + & Fever - & Fever + \\
\hline Positive & 427 & 81 & 584 & 106 \\
\hline Negative & 521 & 66 & 445 & 52 \\
\hline Prevalence & $45.0 \%$ & $55.1 \%$ & $56.8 \%$ & $67.1 \%$ \\
\hline \multirow[t]{2}{*}{ OR } & 1.00 & $1.49(1.05-2.12)$ & 1.00 & $1.55(1.09-2.22)$ \\
\hline & \multicolumn{2}{|c|}{$p$-value $=0.023$} & \multicolumn{2}{|c|}{$p$-value $=0.014$} \\
\hline Thick film & Anaemia - & Anaemia + & Anaemia - & Anaemia + \\
\hline Positive & 228 & 279 & 414 & 280 \\
\hline Negative & 342 & 238 & 336 & 166 \\
\hline Prevalence & $40.0 \%$ & $54.0 \%$ & $55.2 \%$ & $62.8 \%$ \\
\hline \multirow[t]{2}{*}{ OR } & 1.00 & $1.75(1.38-2.23)$ & 1 & $1.36(1.07-1.74)$ \\
\hline & \multicolumn{2}{|c|}{$p$-value $<0.001$} & \multicolumn{2}{|c|}{$p$-value $=0.010$} \\
\hline \multirow[t]{2}{*}{ Thick film } & \multicolumn{2}{|c|}{ Hackett class } & \multicolumn{2}{|c|}{ Hackett class } \\
\hline & Class $=1$ & Class $>1$ & Class $=1$ & Class $>1$ \\
\hline Positive & 405 & 94 & 567 & 118 \\
\hline Negative & 529 & 46 & 495 & 24 \\
\hline Prevalence & $43.4 \%$ & $67.1 \%$ & $53.4 \%$ & $83.1 \%$ \\
\hline \multirow[t]{2}{*}{ OR } & 1.00 & $2.67(1.84-3.91)$ & 1.00 & $4.29(2.77-6.91)$ \\
\hline & \multicolumn{2}{|c|}{$p$-value $<0.001$} & \multicolumn{2}{|c|}{$p$-value $<0.001$} \\
\hline
\end{tabular}

OR odds ratio

age, as shown in Fig. 2b. Among anaemic individuals, the prevalence of Plasmodium infection was $54.0 \%$ in 2010 and $62.8 \%$ in 2011, whereas among non-anaemic individuals, the respective prevalence was 40.0 and $55.2 \%$. Plasmodium infection was significantly more prevalent in people with anaemia than in those without (Table 4).

Splenomegaly and relationship with Plasmodium infection Table 5 shows the extent of splenomegaly within the surveyed population. Most participants (87.0-88.2 \%) had a spleen size of 1 on the Hackett scale. The average Hackett score was $1.23(\mathrm{SD}=0.67)$ in 2010 and $1.22(\mathrm{SD}=0.67)$

Table 5 Distribution of splenomegaly within the study population in the Taabo HDSS, stratified by year of survey

\begin{tabular}{lccc}
\hline Spleen size & $\mathbf{2 0 1 0}$ & $\mathbf{2 0 1 1}$ & \multicolumn{1}{l}{ Total } \\
\hline Hackett class 1 & $934(87.0 \%)$ & $1062(88.2 \%)$ & $1996(87.6 \%)$ \\
Hackett class 2 & $59(5.5 \%)$ & $39(3.2 \%)$ & $98(4.3 \%)$ \\
Hackett class 3 & $52(4.8 \%)$ & $76(6.4 \%)$ & $128(5.6 \%)$ \\
Hackett class 4 & $27(2.5 \%)$ & $23(1.9 \%)$ & $50(2.2 \%)$ \\
Hackett class 5 & $2(0.2 \%)$ & $4(0.3 \%)$ & $6(0.3 \%)$ \\
Total & $1074(100 \%)$ & $1204(100 \%)$ & $2278(100 \%)$ \\
\hline
\end{tabular}

in 2011, with no statistically significant difference between the two surveys.

In the 2010 survey, males had significantly larger spleens than females (Table 6). With regard to participants' residency, the mean spleen sizes measured in 2010 were similar in hamlets, villages and the urban setting, whilst in 2011, spleen sizes were significantly lower in the urban setting compared to villages and hamlets $(p=0.002)$. There was a clear decline in spleen size with

Table 6 Mean spleen size of the sample population in the Taabo HDSS, stratified by year of survey

\begin{tabular}{|c|c|c|c|c|}
\hline & \multicolumn{2}{|l|}{2010} & \multicolumn{2}{|l|}{2011} \\
\hline & Examined & Spleen size & Examined & Spleen size \\
\hline Total & 1074 & 1.23 & 1204 & 1.22 \\
\hline Male & 526 & 1.28 & 559 & 1.26 \\
\hline \multirow[t]{2}{*}{ Female } & 548 & 1.18 & 645 & 1.20 \\
\hline & \multicolumn{2}{|c|}{$p$-value $=0.031$} & \multicolumn{2}{|c|}{$p$-value $=0.135$} \\
\hline Hamlets & 183 & 1.21 & 221 & $1.29^{\mathrm{a}}$ \\
\hline Villages & 703 & 1.25 & 837 & $1.23^{\mathrm{a}}$ \\
\hline \multirow[t]{2}{*}{ Urban } & 188 & 1.17 & 146 & $1.08^{b}$ \\
\hline & \multicolumn{2}{|c|}{$p$-value $=0.210$} & \multicolumn{2}{|c|}{$p$-value $=0.002$} \\
\hline
\end{tabular}

Difference between $a$ and $b$ is significant at level of 0.05 
age (Fig. 2c). Enlarged spleen (Hackett class $>1$ ) was associated with a higher odds of Plasmodium infection (Table 4).

\section{Discussion}

This work presents results from one of the few repeated cross-sectional, population-based malaria prevalence surveys conducted at the district level in a highly malariaendemic setting of West Africa. The study included all age groups, and hence, not only those who are considered at highest risk of malaria (i.e. children below the age of 5 years and women of child bearing age). Furthermore, the study provides stratified data for the three main residential settings of the Taabo HDSS; namely, hamlets, villages and a small town [9]. High Plasmodium infection prevalence rates were recorded in all age groups, ranging from 46.0 to $56.6 \%$. The two cross-sectional surveys were conducted in the rainy season (June/July), which might, at least partially, explain the high prevalence of infection. Levels of Plasmodium infection prevalence observed in the current study were several-fold higher than those reported in a lowland village of Tanzania (13\%) [20], but slightly lower than in previous studies undertaken in central and northern Ghana (58-61 \%) [21, 22]. In the current study in south-central Côte d'Ivoire, the prevalence of Plasmodium infection was somewhat higher in the 2011 survey compared to the preceding year. It will be important to longitudinally monitor Plasmodium infection prevalence in the general population of Côte d'Ivoire as control and elimination efforts are being escalated. The Taabo HDSS offers a unique platform in this regard and will allow for cross-country comparisons [23].

There is evidence that the age-pattern of Plasmodium infection is dependent on the transmission intensity [24]. In areas of low transmission, the risk of infection is similar in all age groups $[25,26]$. Conversely, in highly endemic areas, it is well established that infection rates are higher among children below the age of 5 years, compared to school-aged children, adolescents and adults $[24,27]$. In the current study, highest infection rates were observed in children, particularly those aged 1-9 years. The relatively low prevalence observed in infants (age group $<1$ year) might be explained by the presence of maternal antibodies against malarial antigens, particularly in infants younger than 6 months [28]. For all children, continued exposure to infection may contribute to the development of partial immunity. At the time of this study, based on Plasmodium infection rates in children, the district of Taabo can be classified as being hyperendemic for malaria [19].

Males showed significantly higher infection rates than females. This result is supported by previous studies conducted elsewhere in Africa [29], Asia [30, 31] and
Latin America [32]. This observation might be explained by gender-specific behaviours. It has been suggested that males tend to be more active with outdoors in the evening than females, thus at higher risk of exposure to mosquito bites that transmit malaria [33]. Another plausible explanation is the fact that females are more likely to use preventive measures against mosquito bites (e.g. long clothes, sleeping under LLINs). It could also be that females use prompt treatment once signs and symptoms of malaria are suspected. Further investigations to deepen the understanding of gender-related risk factors for malaria transmission are warranted and the Taabo HDSS provides a platform for this endeavour.

Preceding studies documented higher Plasmodium infection prevalence rates in rural compared to urban areas [34-36]. In the current setting, the prevalence of Plasmodium infection was similar in hamlets and TaaboCité, the only urban area of the Taabo HDSS. This finding indicates that, in the urban setting, ecological conditions are suitable for malaria transmission. A possible explanation is that Taabo-Cité is located in close proximity to Lake Taabo. Surprisingly though, among the rural areas studied, Plasmodium infection was more prevalent in villages than in the less developed hamlets. This observation suggests different risk factors for malaria transmission in the two types of rural settings. Interestingly, different observations have been reported for the western part of Côte d'Ivoire; among children below the age of 15 years, Plasmodium infection rates were similar in villages and hamlets [37].

In the current study, P. falciparum was the predominant malaria species, while only a few individuals were found positive for $P$. malariae and P. ovale. These findings are consistent with epidemiological studies undertaken in 2001 in a single village of the study area [38] and elsewhere in Côte d'Ivoire [39-41]. In sub-Saharan Africa, $P$. malariae and $P$. ovale can reach high prevalence rates [42], but $P$. falciparum is the predominant species [28, 43].

Most infections were of low to moderate parasitaemia with no statistically significant difference between males and females. Although a marked variation in the level of parasitaemia was recorded between villages and the urban setting in 2011, a clear age-pattern was commonly observed in both cross-sectional surveys. This is a reflection of the degree of immunity to the disease, which is known to be low among children, but increases markedly over the time as a result of continuous exposure to Plasmodium infection. In the current study, parasitaemia peaked in children $\leq 9$ years of age, and thereafter showed a substantial decline, suggesting that an effective immune response is acquired in early childhood. This may explain that most infections were asymptomatic. Indeed, only a 
relatively small number of infected persons were found febrile in the community (15.4-21.9\%). However, it is important to note that significant proportions of febrile individuals were diagnosed as having a Plasmodium infection (55.1-67.1\%).

Even though fever was positively associated with Plasmodium infection, a considerable proportion of fever cases (32.9-44.9 \%) showed no Plasmodium infection. This observation raises the question of whether febrile patients should be treated empirically for malaria. In the current study area, presumptive treatment of malaria is common, even in health facilities. As this practice results in overtreatment and might lead to the development of anti-malarial drug resistance, there is a need for RDTs and treatment of only those cases found positive $[8,44]$.

The prevalence of anaemia was high within the surveyed population (37.3-47.6\%). Not surprisingly, children were at highest risk, which is in line with previous studies conducted in Kenya [45], Nigeria [46] and Cameroon [47]. The association between Plasmodium infection and anaemia supports the finding that malaria plays a major role in the occurrence of anaemia in tropical areas [48-50]. Nevertheless, other causes cannot be excluded. In recent surveys conducted in the study area, it was shown that, depending on age groups, Schistosoma haematobium infection, inflammation, cellular iron deficiency and chronic malnutrition must be considered as important contributors to anaemia $[15,51]$. This may explain why high prevalence of anaemia was recorded within the populations. However, a decreasing trend in anaemia was observed over time. Since 2009, several rounds of deworming were administered, which is a probable explanation for the decrease of the proportion of anaemic persons [9].

The proportion of people with enlarged spleen might serve as an indicator for the intensity of malaria transmission [52]. Evidence from the current study suggests that the high proportion of enlarged spleens in the surveyed population might be an indication of latent and chronic infections. Not surprisingly, the data revealed an association between Plasmodium infection and splenomegaly with spleen rates showing similar trends as parasite rates. This is expected for malaria-endemic countries, where transmission is intense and perennial [53-55]. Although malaria is a leading cause of splenomegaly, enlarged spleen is known to be multifactorial [56]. For example, schistosomiasis and other helminthiases should be considered as potential additional causes of splenomegaly. Indeed, in a context of persistent high malaria transmission, the observed decline in the mean spleen size and anaemia from 2010 to 2011 might be explained by the regular deworming targetting schistosomiasis and soil-transmitted helminthiasis.

\section{Conclusion}

This study provides important information on age-, sex- and residency-specific Plasmodium infection rates, parasitaemia and anaemia in the Taabo HDSS where malaria remains the main cause of death. Indeed, the public health significance of malaria calls for concerted efforts to control this mosquitoborne disease. The prevalence of infection was particularly elevated in children below 10 years of age. Males and village residents were at higher risk than females and people living in hamlets or Taabo-Cité. The association between Plasmodium infection and fever, anaemia and splenomegaly, which is a typical feature of heavily endemic areas, demonstrates the severity of the disease. There is, therefore, a pressing need to scale-up control measures in order to reduce the burden of malaria in the Taabo HDSS and Côte d'Ivoire more generally. Further investigations on malaria risk factors will enable a comprehensive overview of the heterogeneities observed within the residence settings and the two genders to come up with setting-specific control interventions.

\section{Abbreviations}

ACT: artemisinin-based combination therapy; CSRS: Centre Suisse de Recherches Scientifiques en Côte d'Ivoire; HDSS: health and demographic surveillance system; Hb: haemoglobin; LLIN: long-lasting insecticidal net; OR: odds ratio; RDT: rapid diagnostic test; SD: standard deviation; WBC: white blood cell; WHO: World Health Organization.

\section{Authors' contributions}

FKB analysed the data and wrote the initial manuscript. MO, KDS and LGA coordinated the data collection. NB and SK coded the data and supervised the data entry. MN and MT were involved in the collection and examination of samples. BB, JU and EKN designed and supervised the study, and revised the manuscript. All authors read and approved the final manuscript.

\section{Author details}

${ }^{1}$ Unité de Formation et de Recherche Biosciences, Université Félix Houphouët-Boigny, Abidjan, Côte d'Ivoire. ${ }^{2}$ Centre Suisse de Recherches Scientifiques en Côte d'Ivoire, Abidjan, Côte d'Ivoire. ${ }^{3}$ Hôpital Général de Taabo, Taabo-Cité, Côte d'Ivoire. ${ }^{4}$ Centre de Recherche et de Lutte contre le Paludisme, Institut National de la Santé Publique, Abidjan, Côte d'Ivoire. ${ }^{5}$ Department of Epidemiology and Public Health, Swiss Tropical and Public Health Institute, Basel, Switzerland. ${ }^{6}$ University of Basel, Basel, Switzerland.

\section{Acknowledgements}

We thank the political and health authorities and all the inhabitants of the study area for their excellent cooperation. We are grateful to all the staff of the Taabo HDSS for their logistic support during this work. Special thanks are addressed to the laboratory technicians who read the thick and thin blood films. The research was funded by Fairmed (Bern, Switzerland).

\section{Competing interests}

The authors declare that they have no competing interests.

Received: 30 April 2015 Accepted: 23 December 2015

Published online: 06 January 2016

\section{References}

1. Kabir MM, Naher S, Islam A, Karim A, Rasid MH, Laskar SI. Vector contro using LLIN/ITN: reduction of malaria morbidity in Bengladesh. Malar J. 2014;13:47. 
2. Porras Ramirez A, Buitrago JIG, González JPP, Moráles AH, Frequency Carrasquilla G. Tendency of malaria in Colombia, to 2011: a descriptive study. Malar J. 1990;2014(13):202.

3. WHO. World malaria report 2013. Geneva: World Health Organization; 2013.

4. Eholié SP, Ehui E, Adou-Bryn K, Kouamé KE, Tanon A, Kakou A, et al. Paludisme grave de l'adulte autochtone à Abidjan (Côte d'Ivoire). Bull Soc Pathol Exot. 2004;97:340-4.

5. Wang SJ, Lengeler C, Smith TA, Vounatsou P, Cissé G, Tanner M. Rapid urban malaria appraisal (RUMA) III: epidemiology of urban malaria in the municipality of Yopougon (Abidjan). Malar J. 2006;5:29.

6. Assoumou A, Adoubryn KD, Aboum KS, Kouadio-Yapo CG, Ouhon J. Portage symptomatique et asymptomatique de Plasmodium falciparum chez les enfants de 6 mois à 6 ans à I'hôpital général d'Abobo (Abidjan, Côte d'Ivoire). Bull Soc Pathol Exot. 2008;101:50-3.

7. Rowe AK, Kachur PK, Yoon SS, Lynch M, Slutsker L, Steketee RW. Caution is required when using health facility-based data to evaluate the health impact of malaria control efforts in Africa. Malar J. 2009;8:209.

8. D’Acremont V, Kilowoko M, Kyungu E, Philipina S, Sangu W, Kahama-Maro J, et al. Beyond malaria: causes of fever in outpatient Tanzanian children. N Engl J Med. 2014;370:809-17.

9. Koné S, Baikoro N, N'Guessan Y, Jaeger FN, Silué KD, Fürst T, et al. Health and demographic surveillance system profile: the Taabo health and demographic surveillance system, Côte d'Ivoire. Int J Epidemiol. 2015:44:87-97.

10. Koné S, Fürst T, Jaeger FN, Esso ELJC, Baikoro N, Adiossan GL, et al. Causes of death in the Taabo health and demographic surveillance system, Côte d'Ivoire, from 2009 to 2011. Glob Health Action. 2015;8:27271.

11. Diomandé $M$, Dongo K, Djé KB, Kouadio KKH, Koné D, Biémi J, et al. Vers un changement du calendrier cultural dans l'écotone forêt-savane de la Côte d'Ivoire. Agron Afr. 2013;25:133-47.

12. N'Goran EK, Diabaté S, Utzinger J, Sellin B. Changes in human schistosomiasis levels after the construction of two large hydroelectric dams in central Côte d'Ivoire. Bull World Health Organ. 1997;75:541-5.

13. Glinz D, N'Guessan NA, Utzinger J, N'Goran EK. High prevalence of Strongyloides stercoralis among schoolchildren in rural Côte d'Ivoire. J Parasitol. 2010;96:431-3.

14. Becker SL, Sieto B, Silue' KD, Adjossan I, Koné S, Hatz C, et al. Diagnosis, clinical features, and self-reported morbidity of Strongyloides stercoralis and hookworm infection in a co-endemic setting. PLoS Negl Trop Dis. 2011;5:e1292.

15. Righetti AA, Koua AYG, Adiossan LG, Glinz D, Hurrell RF, N'Goran EK, et al. Etiology of anemia among infants, school-aged children, and young nonpregnant women in different settings of south-central Côte d'Ivoire. Am J Trop Med Hyg. 2012;87:425-34.

16. WHO. Malaria rapid diagnostic test performance: results of WHO product testing of malaria RDTs: round 3 (2010-2011). Geneva: World Health Organization; 2011

17. Hackett LW. Spleen measurement in malaria. J Natl Malar Soc. 1944;3:121-34.

18. WHO. Iron deficiency anemia: Assessment, prevention and control: A guide for programme managers. Geneva: World Health Organization; 2001.

19. WHO. Terminology of malaria and malaria eradication. Geneva: World Health Organization; 1963

20. Mmbando BP, Vestergaard LS, Kitua AY, Lemnge MM, Theander TG, Lusingu JPA. A progressive declining in the burden of malaria in northeastern Tanzania. Malar J. 2010;9:216.

21. Koram KA, Owusu-Agyei S, Fryauff DJ, Anto F, Atuguba F, Hodgson A, et al. Seasonal profiles of malaria infection, anemia, and bednet use among age groups and communities in northern Ghana. Trop Med Int Health. 2003:8:793-802.

22. Owusu-Agyei S, Asante KP, Adjuik M, Adjei G, Awini E, Adams M, et al. Epidemiology of malaria in the forest-savanna transitional zone of Ghana. Malar J. 2009;8:220.

23. Streatfield PK, Khan A, Bhuiya A, Alam N, Sié A, Soura AB, et al. Causespecific mortality in Africa and Asia: evidence from Indepth health and demographic surveillance system sites. Glob Health Action. 2014;7:5362.

24. Carneiro I, Roca-Feltrer A, Griffin JT, Smith L, Tanner M, Schellenberg JA, et al. Age-patterns of Malaria vary with severity, transmission intensity and seasonality in sub-Saharan Africa: a systematic review and pooled analysis. PLoS One. 2010;5:e8988.

25. Diop A, Konate L, Molez JF, Diouf M, Gaye O, Fontenille D, et al. Le paludisme en zone de mangrove du delta du Saloum (Sénégal). Environ Risq Santé. 2006;5:93-8.

26. Graves PM, Richards FO, Ngondi J, Emerson PM, Shargie EB, Endeshaw T, et al. Individual, household and environmental risk factors for malaria infection in Amhara, Oromia and SNNP regions of Ethiopia. Trans R Soc Trop Med Hyg. 2008;2009(103):1211-20. doi:10.1016/j.trstmh.11.016.

27. Geiger C, Agustar HK, Compaoré G, Coulibaly B, Sié A, Becher H, et al. Declining malaria parasite prevalence and trends of asymptomatic parasitaemia in a seasonal transmission setting in north-western Burkina Faso between 2000 and 2009-2012. Malar J. 2013;12:27.

28. Snow RW, Nahlen B, Palmer A, Donnelly CA, Gupta S, Marsh K. Risk of severe malaria among African infants: direct evidence of clinical protection during early infancy. J Infect Dis. 1998;177:819-22.

29. Owusu-Agyei S, Koram KA, Baird JK, Utz GC, Binka FN, Nkrumah FK, et al. Incidence of symptomatic and asymptomatic Plasmodium falciparum infection following curative therapy in adult residents of Northern Ghana. Am J Trop Med Hyg. 2001;65:197-203.

30. Erhart A, Thang ND, Hung NQ, le Toi V, le Hung X, Tuy TQ, et al. Forest malaria in Vietnam: a challenge for control. Am J Trop Med Hyg. 2004;70:110-8.

31. Reza YM, Taghi RM. Prevalence of malaria infection in Sarbaz, Sistan and Bluchistan province. Asian Pac J Trop Biomed. 2011;1:491-2.

32. Cucunubá ZM, Guerra AP, Rahirant SJ, Rivera JA, Cortés LJ, Nicholls RS. Asymptomatic Plasmodium spp. infection in Tierralta, Colombia. Mem Inst Oswaldo Cruz. 2008;103:668-73.

33. Kimbi HK, Keka FC, Nyabeyeu HN, Ajeagah HU, Tonga CF, Lum E, et al. An update of asymptomatic falciparum malaria in school children in Muea, Southwest Cameroon. J Bacteriol Parasitol. 2012;3:8

34. Gardiner C, Biggar RJ, Collins WE, Nkrumah FK. Malaria in urban and rural areas of southern Ghana: a survey of parasitaemia, antibodies, and antimalarial practices. Bull World Health Organ. 1984;62:607-13.

35. Le Gazin P. paludisme en Afrique au sud du Sahara: comparaison entre les milieux urbains et ruraux. Cahiers Santé. 1991;1:33-8.

36. De Beaudrap P, Nabasumba C, Grandesso F, Turyakira E, Schramm B, Boum $Y$, et al. Heterogeneous decrease in malaria prevalence in children over a six-year period in south-western Uganda. Malar J. 2011;10:132.

37. N'Zeyimana I, Henry MC, Dossou-Yovo J, Doannio JMC, Diawara L, Carnevale P. Epidémiologie du paludisme dans le sud-ouest forestier de la Côte d'Ivoire (Région de Tai). Bull Soc Pathol Exot. 2002;95:89-94.

38. Silué KD, Felger I, Utzinger J, Beck HP, Smith TA, Tanner M, et al. Prévalence, diversité antigénique et multiplicité d'infections de Plasmodium falciparum en milieu scolaire au centre de la Côte d'Ivoire. Med Trop (Mars). 2006;66:149-56.

39. Dossou-Yovo J, Ouattara A, Doannio JMC, Rivière E, Chauvancy G, Meunier $Y$. Aspects du paludisme dans un village de savane humide de Côte d'Ivoire. Med Trop (Mars). 1994;54:331-6.

40. Raso G, Luginbühl A, Adjoua CA, Tian-Bi NT, Silué KD, Matthys B, et al. Multiple parasite infections and their relationship to self-reported morbidity in a community of rural Côte d'Ivoire. Int J Epidemiol. 2004;33:1092-102.

41. Diakité NR, Adja AM, Von Stamm T, Utzinger J, N'Goran EK. Situation épidémiologique avant la mise en eau du barrage hydroagricole de cinq villages de Bouaké, centre Côte d'Ivoire. Bull Soc Pathol Exot. 2010;103:22-8.

42. Mueller I, Zimmerman PA, Reeder JC. Plasmodium malariae and Plasmodium ovale - the 'bashful' malaria parasites. Trends Parasitol. 2007;23:279-83.

43. Munyekenye OG, Githeko AK, Zhou G, Mushinzimana E, Minakawa N, Yan G. Plasmodium falciparum spatial analysis, Western Kenya Highlands. Emerg Infect Dis. 2005;11:1571-7.

44. WHO. Guidelines for the treatment of malaria, vol. 2nd edition. Geneva: World Health Organization; 2010.

45. Desai MR, Terlouw DJ, Kwena AM, Phillips-Howard PA, Kariuki SK, Wannemuehler KA, et al. Factors associated with hemoglobin concentrations in pre-school children in Western Kenya: cross-sectional studies. Am J Trop Med Hyg. 2005;72:47-59.

46. Bamidele JO, Abodunrin OL, Olajide FO, Oke YF. Prevalence and determinants of anemia among school pupils of a peri-urban community in Osun State. Nigeria. Int J Adolesc Med Health. 2010;22:461-8. 
47. Sumbele IUN, Samje M, Nkuo-Akenji T. A longitudinal study on anaemia in children with Plasmodium falciparum infection in the Mount Cameroon region: prevalence, risk factors and perceptions by caregivers. BMC Infect Dis. 2013;13:123.

48. Akhwale WS, Lum JK, Kaneko A, Eto H, Obonyo C, Björkman A, et al. Anemia and malaria at different altitudes in the western highlands of Kenya. Acta Trop. 2004;91:167-75

49. Pluess B, Mueller I, Levi D, King G. Smith1 TA, Lengeler C. Malaria: a major health problem within an oil palm plantation around Popondetta, Papua New Guinea. Malar J. 2009:8:56.

50. Agu PU, Ogboi JS, Akpoigbe K, Okeke T, Ezugwu E. Impact of Plasmodium falciparum and hookworm infections on the frequency of anaemia in pregnant women of rural communities in Enugu, South East Nigeria. Pan African Med J. 2013;14:27.

51. Righetti AA, Adiossan LG, Ouattara M, Glinz D, Hurrell RF, N'Goran EK, et al. Dynamics of anemia in relation to parasitic infections, micronutrient status, and increasing age in south-central Côte d'Ivoire. J Infect Dis. 2013;207:1604-15.
52. Rogier C, Henry MC, Trape JF. Evaluation épidémiologique du paludisme en zone d'endémie. Med Trop (Mars). 2009;69:123-42.

53. Dolo A, Camara F, Poudiougo B, Touré A, Kouriba B, Bagayogo M, et al. Épidémiologie du paludisme dans un village de savane soudanienne du Mali (Bancoumana). 2. Étude entomo-parasitologique et clinique. Bull Soc Pathol Exot. 2003;96:308-12.

54. Mueller I, Kundi J, Bjorge S, Namuigi P, Saleu G, Riley IA, et al. The epidemiology of malaria in the Papua New Guinea highlands: 3. Simbu Province. PNG Med J. 2004;47:159-73.

55. Mukhopadhyay DK, Chkraborty M, Ganguly U, Biswas R, Joadar GK, Karmakar PR. Malaria and asymptomatic parasitemia: an experience from a forest village of Sub-Himalayan West Bengal. India. Indian J Soc Med. 2010;41:97-100

56. Weinreb NJ, Rosenbloom BE. Splenomegaly, hypersplenism, and hereditary disorders with splenomegaly. Open J Genet. 2013;3:24-43.

\section{Submit your next manuscript to BioMed Central and we will help you at every step:}

- We accept pre-submission inquiries

- Our selector tool helps you to find the most relevant journal

- We provide round the clock customer support

- Convenient online submission

- Thorough peer review

- Inclusion in PubMed and all major indexing services

- Maximum visibility for your research

Submit your manuscript at www.biomedcentral.com/submit
(O) BioMed Central 